\title{
SOIL VS. CANOPY SEED STORAGE AND PLANT SPECIES COEXISTENCE IN SPECIES-RICH AUSTRALIAN SHRUBLANDS
}

\author{
N. J. Enright, ${ }^{1,3,4}$ E. Mosner, ${ }^{2}$ B. P. Miller,,${ }^{1,3}$ N. Johnson, ${ }^{3}$ and Byron B. Lamont ${ }^{3}$ \\ ${ }^{1}$ Geography Program, School of Social and Environmental Enquiry, University of Melbourne, Melbourne, \\ Victoria 3010 Australia \\ ${ }^{2}$ Plant Ecology and Nature Conservation, University of Potsdam, Maulbeeralle 2, Potsdam 14469 Germany \\ ${ }^{3}$ Centre for Ecosystem Diversity and Dynamics, Department of Environmental Biology, Curtin University of Technology, \\ P.O. Box U1987, Perth, Western Australia 6845 Australia
}

\begin{abstract}
The fire-prone shrublands of southwestern Australia are renowned for their high plant species diversity and prominence of canopy seed storage (serotiny). We compared species richness, abundance, and life history attributes for soil and canopy seed banks in relation to extant vegetation among four sites with different substrate conditions and high species turnover (50-80\%) to identify whether this unusual community-level organization of seed storage might contribute to maintenance of high species richness.

Soil seed bank (SSB) densities were low to moderate (233-1435 seeds $/ \mathrm{m}^{2}$ ) compared with densities for other Mediterranean-type vegetation and were lowest for sites with highest canopy seed bank (CSB) species richness and lowest nutrient availability, but not richness or abundance of resprouters. Annuals were infrequent in the lowest nutrient sites, but there was no evidence that small SSB size was due to low seed inputs or a trade-off between seed production/storage and seed size in response to low nutrient availability. Sorensen's similarity between SSB and extant vegetation was $26-43 \%$ but increased to $54-57 \%$ when the CSB was included, representing levels higher than reported for most other ecosystems. Resprouting species were well represented in both the SSB and CSB, and there was no evidence for lower seed production in resprouters than in non-sprouters overall. The SSB and CSB held no species in common and were characterized by markedly different seed dispersal attributes, with winged or small seeds in the CSB and seeds dispersed by ants, birds, and wind (though none with wings) in the SSB. There was no evidence of spatial differentiation in the distribution of seeds of SSB species between vegetated and open microsites that might facilitate species coexistence, but most woody non-sprouters showed aggregation at scales of 1-2 m, implying limited seed dispersal. High similarity between overall seed bank (SSB + CSB) and extant species composition, high number of resprouting species, and seed dispersal processes before (SSB) and after fire (CSB) leading to differential spatial aggregation of postfire recruits from the two seed bank types may buffer species composition against rapid change and provide a mechanism for maintaining species coexistence at the local scale.
\end{abstract}

Key words: canopy seed bank; coexistence; fire; serotiny; shrublands; soil seed bank; southwestern Australia; species richness.

\section{INTRODUCTION}

Persistent soil-stored seed banks (SSB) are common in fire-prone ecosystems and reflect adaptations of plant species such that recruitment is cued to fire and its associated reductions in competition for light, nutrients, moisture, and space (Bell et al. 1993). Seeds of fire ephemerals and longer-lived perennials may be stored in the soil for several to many years, with release from dormancy triggered by the effects of heat and smoke associated with fires (Enright and Kintrup 2001). Storage of seeds in woody fruits or cones in the living plant crown for several to many years (serotiny; Lamont

Manuscript received 8 August 2006; revised 20 December 2006; accepted 23 January 2007. Corresponding Editor: D. P. C. Peters.

${ }^{4}$ E-mail: neal@unimelb.edu.au et al. 1991) is also prominent in many fire-prone ecosystems. Some canopy-stored seeds may be released during inter-fire periods as fruits open with increasing age in the absence of fire, but most are released en masse due to the heat of fire. Germination occurs in the first growing season after release, or the seeds perish (i.e., seeds do not become part of a persistent SSB).

Fire-prone forests, woodlands, and shrublands in the Northern Hemisphere may be dominated by a few serotinous conifers, e.g., Pinus halapensis in the Mediterranean Basin (Ne'eman et al. 2004) and species in the genera Pinus, Cupressus, and Sequoiadendron in North America (Lamont et al. 1991, Keeley and Zedler 1998). While such species can hold a large store of seeds, they make only a small contribution to the overall species richness of the seed store (mostly held in the soil) that contributes to post-fire vegetation development (Ne'eman and Izhaki 1999). In contrast, in fire-prone 
woodlands and shrublands of Australia and South Africa (but most particularly southwestern Australia) several to many serotinous species commonly coexist (Lamont et al. 1991). In such plant communities, the canopy seed bank (CSB) is a potential repository of species richness analogous to the SSB, but its attributes and role in community-level dynamics in relation to fire have received little attention other than for demographic studies of individual species (Enright et al. 1996). Only two studies have quantified canopy seed storage at the community level (Bellairs and Bell 1990, 1993), both for sites in southwestern Australia.

The size of SSBs in Mediterranean-type shrublands and woodlands ranges from very low to very high, relative to those reported for other ecosystem types: Bellairs and Bell (1993) reported a germinable SSB density of only 156 seeds $/ \mathrm{m}^{2}$ for a southwestern Australian shrubland. Holmes and Cowling (1997) recorded SSB densities of $1100-1500$ seeds $/ \mathrm{m}^{2}$ for Cape fynbos, little correspondence between species composition of the SSB and extant vegetation, mostly due to the presence of ephemeral species in the seed bank, and dominance of resprouting species characterized by low seed production in the extant vegetation. Ne'eman and Izhaki (1999) recorded low to moderate germinable seed densities $\left(300-1300\right.$ seeds $\left./ \mathrm{m}^{2}\right)$ in the SSB of east Mediterranean Aleppo pine (Pinus halapensis) forests, and a low correlation between extant species and seed bank composition, mainly due to the absence of resprouting woody species in the seed bank. Valbuena and Trabaud (2001) obtained similar results for shrublands in Spain (1050-1800 seeds $\left./ \mathrm{m}^{2}\right)$, with only $23 \%$ of species in common between extant vegetation and the SSB. Short-lived herbaceous and grass species were prominent in the seed bank but not in the extant vegetation. Soil seed bank densities of 8000-25000 seeds $/ \mathrm{m}^{2}$ were estimated for Californian chaparral by Zammit and Zedler (1988) in sites 9, 35, and 65 years since last fire. While the shrub species Adenostoma fasciculatum strongly dominated the seed bank, densities after excluding this species were still high (5000-6000 seeds $/ \mathrm{m}^{2}$ ) relative to those recorded in other Mediterranean-type shrublands and woodlands.

Small SSB size in some Mediterranean-type ecosystems could result from one or more of the following; (1) strong dominance of species that recover vegetatively after fire (resprouters) (Bell 2001), since these generally produce fewer seeds than do fire-killed congeners (Enright and Lamont 1989, Lamont and Weins 2003) and are not wholly dependent upon seeds to retain their place in the community; (2) a high frequency of occurrence of serotinous species that store their seeds on the plant rather than in the soil (Lamont et al. 1991); and (3) a large seed size vs. low seed number trade-off in nutrient-impoverished sites (Milberg et al. 1998, Parolin 2000) such as the Mediterranean-type shrubland ecosystems of Australia (and South Africa), also resulting in low richness of annuals (Cowling et al. 1996).
The persistent SSB in temperate woody ecosystems is generally dominated by early successional species, so that long-lived taxa typical of the extant vegetation are absent or only poorly represented (Thompson 1978, 2000), and this is also true for some (Holmes and Cowling 1997), but not all (Wills and Read 2002), fireprone shrublands. In contrast, the CSB must be supported by long-lived aboveground plant tissues so that, by definition, it is restricted to extant woody perennials. The Mediterranean-type shrublands of southwestern Australia are renowned for their high species richness, and the mechanisms facilitating species coexistence in such ecosystems have been the topic of long-standing conjecture (Lamont et al. 1977, Cowling 1987, Bond et al. 1992). Differences in seed bank attributes between the CSB and SSB could contribute to species coexistence by affecting the spatial distributions of seeds and, so, patterns of post-fire recruitment. The dispersal kernels for different plant species depends largely upon the mode of dispersal and height of seed release, with dispersal of only a few meters in antdispersed species (Anderson and Morrison 1998) but much greater distances in wind- and vertebrate-dispersed species (Nathan et al. 2001). Seidler and Plotkin (2006) have shown that extent and scale of spatial pattern in tropical tree species correlates with dispersal mode.

Incomplete vegetation cover also characterizes these shrublands, with patches of bare ground from one to several square meters between areas of dense vegetation. Differences in SSB composition between bare and vegetated patches might further differentiate species distributions, with small-seeded species dispersed more uniformly across micro-site types than large-seeded species, reflecting stronger "colonizer" ability in smallseeded species (Holmes and Wilson 1998, Figueroa et al. 2004). Factors that could lead to spatial differentiation in the regeneration niches of species in the CSB and SSB thus include differences in seed dispersal vectors and distances and the patterns and extent of seed dispersal into different micro-site types.

Our study quantified the SSB and CSB of four representative Mediterranean-type shrubland types in the northern sandplains of southwestern Australia, characterized by high species richness, abundance of serotinous and resprouting species, and low-nutrient soils, and posed the following hypotheses as a focus for considering the role of the two seed banks in contributing to species coexistence in this fire-prone ecosystem:

1) Soil seed bank size is small compared with seed banks in most other ecosystem types since vegetative recovery and serotiny provide alternative persistence pathways to soil seed storage and are exceptionally wellrepresented in these shrublands.

2) Soil seed bank size is small due to low seed inputs, since nutrient-poor soils are unfavorable for recruitment of small-seeded, annual species, whereas species at such sites tend to be perennials producing a few large seeds. 


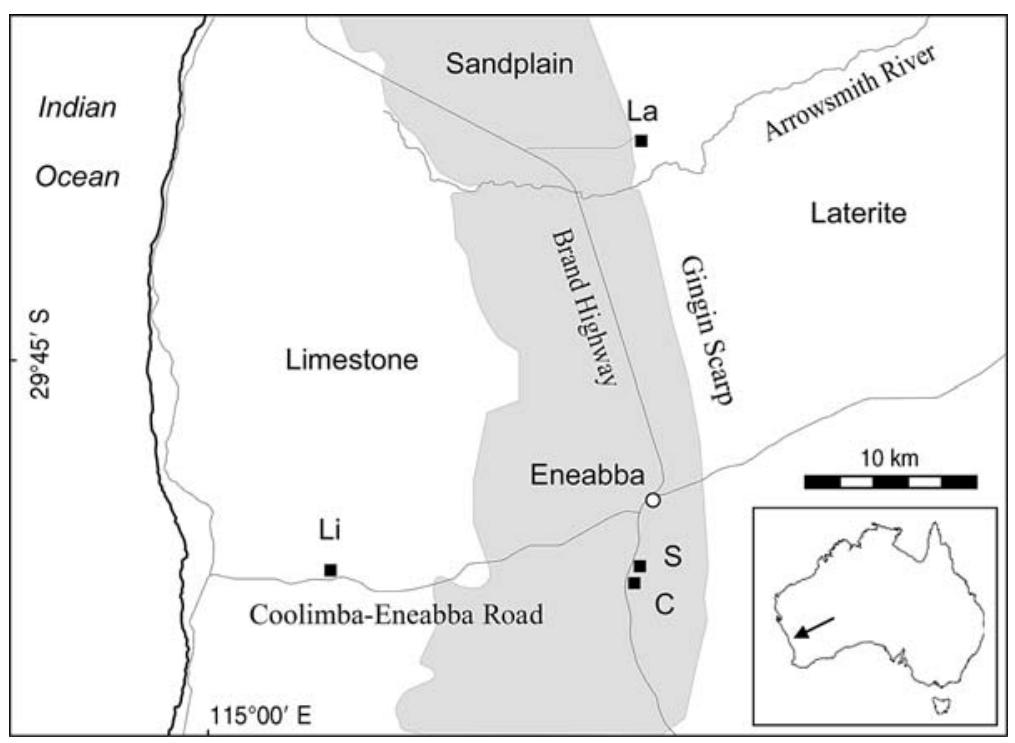

FIG. 1. Location of the four shrubland study sites (solid squares) near Eneabba, southwestern Australia (C, Crest; S, Swale; La, Laterite; Li, Limestone), in relation to substrate types (sandplain, limestone, laterite), major roads, Gingin Scarp (which runs approximately north-south and forms the boundary between acid sandplain and lateritic substrates), and the Indian Ocean. The inset map of Australia shows the general location of the study area (indicated by the arrow).

3) Resprouting species are more poorly represented than non-sprouting species (richness and density) in both the CSB and SSB since seed production in them is generally low compared with that for non-sprouting species.

4) Soil seed bank species composition will show only a weak relationship with extant vegetation, but the relationship between overall seed bank composition $(\mathrm{SSB}+\mathrm{CSB})$ and extant vegetation will be high relative to other ecosystems due to the high contribution made by CSB species, so contributing to maintenance of extant species richness.

5) Differences between SSB and CSB species in seed dispersal attributes, and within SSB species for open vs. vegetated patches, may help to spatially structure seed bank distributions so that competition between species as post-fire recruits is reduced, facilitating coexistence and the maintenance of high species richness in these shrublands.

\section{Methods \\ Study area}

Within the extensive Mediterranean-type shrublands ("kwongan") of the mid-west region of southwestern Australia near Eneabba, 270-300 km north of Perth, there are four sub-communities with differing species composition and structure determined by substrate type. Hnatiuk and Hopkins (1981) describe tall shrublands on low sandy dunes and low shrublands on adjacent flatlands of the Eneabba Sandplain with structure and composition influenced primarily by the effects of soil depth on water availability (Enright and Lamont 1992). Extensive, tall shrublands on calcareous substrates occur west of the
Eneabba Sandplain, and low shrublands on shallow sands over laterite occur to the east of the sandplain (Fig. 1). These shrublands are fire-prone, with an estimated mean fire interval of 13 years over the last 30 years (Enright et al. 2005). Most extant plant species show adaptations to cope with fire, including the ability to recover vegetatively, firestimulated germination of soil-stored seeds, and release of canopy-stored seeds (Enright and Lamont 1989). Hnatiuk and Hopkins (1981) report species richness of up to 130 species $/ 100 \mathrm{~m}^{2}$ for sample quadrats in the South Eneabba Flora Reserve.

Field data were collected at one site for each substrate type: (1) a sandy dune crest (hereafter called "Crest"), with deep, unconsolidated acid sands to $5 \mathrm{~m}$; (2) adjacent flatlands ("Swale"), comprising shallow, unconsolidated acid sands (to $1 \mathrm{~m}$ ) over clay; (3) a lateritic soil site ("Laterite"), with shallow acid sands $(<0.5 \mathrm{~m})$ over gravels rich in iron and aluminium; and (4) unconsolidated calcareous sands over Quaternary limestone ("Limestone"). Sites were selected on the basis of vegetation age (mature phase vegetation, last burned 1220 years ago) and absence of human disturbance, using geological and fire history maps and satellite images, followed by field inspection (Fig. 1). We chose to compare shrubland sites on different substrates with different species compositions rather than replicate sites on a single substrate in order to test for common explanations among sites with different seed bank attributes for the hypotheses presented. The size and intensity of sampling of vegetation and seed bank sites (as described below) precluded replication within shrubland types. 


\section{Data collection}

Extant vegetation was quantified for a single location at each site using plots ranging in size from $30 \times 30 \mathrm{~m}$ at Swale and Laterite to $40 \times 40 \mathrm{~m}$ at Crest and Limestone. For each site, plot size was determined based on the area needed to sample a minimum of 10000 perennial individuals since sites were established for long-term ecological study, including spatial analyses in which number of individuals is a more important criterion than area sampled. The identity of every perennial plant $>10$ $\mathrm{cm}$ height or canopy width was recorded within contiguous $5 \times 5 \mathrm{~m}$ subplots, and the spatial position where plant stems emerged from the ground was recorded as the distance from each of two known subplot corners. These values were later converted to $x$, $y$ coordinates. For clonal plants, spatial position was recorded as the center of the patch of ramets. Presence of winter annuals and herbaceous plant species $<10 \mathrm{~cm}$ that die off above ground in summer was recorded (in winter/spring) but not mapped.

Ninety random locations were identified within each plot, and a single surface soil sample of size $14 \times 14 \times 5$ $\mathrm{cm}$ (depth) was collected from each using a custom-built sampler. A large number of samples per plot and large soil area per sample were chosen since the combination of known high species richness and predicted low SSB density meant that sample variance for species composition and density was likely to be high. Based on individual samples of much smaller diameters (1.9-4.7 $\mathrm{cm}$ ), Gross (1990) and Butler and Chazdon (1998) concluded that 60-74 soil samples were needed to provide sound estimates of SSB density and richness. Only the top $5 \mathrm{~cm}$ of soil was sampled since it contains the greatest density of soil-stored seeds (Grant and Koch 1997), seeds stored deeper in the soil are unlikely to receive the cues required for post-fire germination, and germinants are unlikely to emerge from such depths in any case (Brown et al. 2003). Samples were collected in April (autumn) after most extant species had completed seeding and prior to winter germination of annuals, so that SSB size was at its annual maximum.

Each SSB sample location was classified either as bare (exposed sand, no overhanging plant canopy) or vegetated (overhanging foliage present), percentage of projective foliage cover was estimated subjectively and surface litter was collected, dried, and weighed. Soil samples were thoroughly mixed, and two 10-g subsamples were removed from each for nutrient analysis. The remainder was treated to maximize germination of seeds; samples were saturated with boiling water (achieving a maximum temperature of $80^{\circ} \mathrm{C}$ ), spread over a perlite/coarse sand (1:1) mix in germination trays to $2 \mathrm{~cm}$ depth, and then soaked for $24 \mathrm{~h}$ with a $1: 10$ aqueous smoke: water solution (Murray Plains smoked water, Murray Joblink, Pinjarra, Australia). These procedures have been shown to promote maximum germination of plant species in which seed dormancy is broken by heat and/or smoke (Enright and Kintrup
2001). Germination was followed in a glasshouse for 150 days. Germination tray positions were randomized within the glasshouse, and control trays containing only the perlite/coarse sand mix were used to identify contaminant seeds entering trays after their placement in the glasshouse. Total soil N and S, Colwell's P and K, and soil $\mathrm{pH}$ were analyzed by CSBP Wesfarmers, Perth, Australia, and exchangeable cations ( $\mathrm{Ca}, \mathrm{Mg} \mathrm{K}, \mathrm{Na}$ ) by the authors at Curtin University of Technology, Perth, using the ammonium acetate leachate method (Rayment and Higginson 1992).

The CSB was estimated for serotinous species using the following procedure: where extant plant density for a serotinous species within a plot was $>10$, a random sample of 10 individuals was selected. The size of each plant (height, diameter of crown) and the number of serotinous fruits on the plant were recorded. A further 10 plants were sampled from outside the plot (the first 10 plants encountered beyond a buffer zone of $5 \mathrm{~m}$ from the plot edges), with a sample of fruits collected from each of these plants only. Seed stores on plants inside the plots were not disturbed since plots have been established as long-term monitoring sites for each shrubland type. Where there were $<10$ plants in the plot, all plants were quantified for size and number of fruits, and a search was made outside the plots until the sample size was 20. Level of serotiny was assessed in the field for five plants per serotinous species as the number of years for which seeds were held within closed fruits in the crown. In many species, fruits could be aged precisely by relating fruit position to annual growth node scars on stems. Where this was not possible, fruit age estimates were based on the physical appearance of fruits and could only be assigned to more general age classes. For this reason, level of serotiny was assigned to each species on a five-point scale: $1=$ seeds held for $1-2 \mathrm{yr}, 2=>2-4$ $\mathrm{yr}, 3=>4-6 \mathrm{yr}, 4=>6-10 \mathrm{yr}, 5=>10 \mathrm{yr}$.

In some species, collected fruits released their seeds quickly upon air drying at room temperature, while in others, oven drying at $60-100^{\circ} \mathrm{C}$ for $24 \mathrm{~h}$ or surface scorching of the fruits over an open flame followed by wetting and drying (Cowling and Lamont 1985) was required to facilitate seed release. Seeds per fruit were counted and sorted into aborted (empty, no embryo apparent), eaten (e.g., insect exit hole in fruit, insect or frass present), and firm (embryo present), and numbers of firm seeds per fruit and per plant were estimated. Germination rate of firm seeds was tested for replicate batches of seeds (sample sizes $5 \times 10$ seeds or $5 \times 20$ seeds, depending on seed availability) on moist filter paper in Petri dishes in a growth cabinet at $18^{\circ} \mathrm{C}$. For species with seed mass $\leq 0.1 \mathrm{mg}$ equal masses of seeds were placed in replicate dishes, and seed numbers were counted subsequently using a binocular microscope. The CSB and SSB were compared based on the number of germinable seeds per square meter: in the case of SSB, using bulk germination of surface soil samples, and for CSB, using the number of germinable seeds per plant 
TABLE 1. Floristic richness (number of species) of extant species for four shrubland sites near Eneabba, southwestern Australia, in relation to mode of regeneration and seed storage.

\begin{tabular}{lcccccc}
\hline \hline Site & Total plant species & Non-sprouters & Resprouters & Annuals & Soil storage & Canopy storage \\
\hline Crest & 114 & 39 & 75 & $3(1)$ & $81(51)$ & 28 \\
Swale & 104 & 26 & 78 & $4(0)$ & $75(35)$ & 29 \\
Laterite & 95 & 21 & 74 & $3(2)$ & $72(34)$ & 22 \\
$60(32)$ & 12 & 75 & 164 & $15(3)$ & $191(101)$ & 53 \\
All & 263 & & & & \\
\hline
\end{tabular}

Notes: Numbers in parentheses for annuals are exotic annuals. Numbers in parentheses for soil storage show number of woody species as a subset of all species with soil storage. Non-sprouter numbers also include annuals. Soil storage refers to species whose seeds remain dormant in the soil for $>1$ year following dispersal, requiring a disturbance-related trigger (e.g., heat or smoke from fire) to break dormancy and facilitate germination. Canopy storage refers to species whose seeds are held in a state of enforced dormancy within closed fruits in the plant canopy for $>1$ year so that overlapping annual seed crops accumulate on the plant. Canopy-storage fruits rupture and release their seeds in response to the heat from fires (and sometimes in response to drought, plant death, or fruit aging); the seeds then germinate as soon as appropriate temperature and moisture conditions are encountered.

adjusted to an area estimate based on the number of individuals of each species in the sampled vegetation plots.

The high species richness of the study sites, including many species within the same genus, made identification to species level of seedlings from the SSB difficult, and resulted in seed bank densities too low for statistical analysis in many taxa. For these reasons, analyses (analysis of variance models and chi-square tests, as appropriate) were performed for broader groupings based on life history attributes. Life history attributes of all plant species (extant, CSB, and SSB) including life form (shrub, sub-shrub, herb, grass/sedge), regeneration mode (resprouter/non-sprouter), longevity (annual/perennial), seed size, and dispersal mode, were determined based on field observations and collections, published accounts, and taxonomic descriptions. Dispersal modes used were: wind (anemochores; winged or plumed seeds), ant (myrmechocores), bird (internal), bird/mammal (external, burr), mobile (barochores; small seeds $<0.2 \mathrm{mg}$ dispersal unit mass), and none (no apparent dispersal adaptation, dispersal unit mass $>0.2 \mathrm{mg}$ ). Seed size was categorized as large (dispersal unit mass $>20$ $\mathrm{mg}$ ), medium $(2-20 \mathrm{mg})$, and small $(<2 \mathrm{mg})$.

Similarity in species composition among sites for extant vegetation, CSB, and SSB was estimated using Sorensen's index (McCune and Mefford 1999). This index is a semi-metric measure based on species presence data. It is directly related to the quantitative Bray-Curtis similarity measure, which returns identical values to Sorensen's index when abundance data are reduced to presence/absence (McCune and Mefford 1999). Jackknife 1 and 2 richness estimators were used to estimate total SSB species richness per site and the number of species likely to have been missed by the SSB sampling. Jackknifes were calculated using the data summary procedure in PC-ORD version 4.0 (McCune and Mefford 1999) and were chosen as the best performed estimators based on analyses of extant vegetation richness at these same sites (Chiarucci et al. 2003).

Spatial pattern for species in the SSB was explored using spatial autocorrelation analysis (Moran's $I$ and Geary's C; Legendre and Legendre 1998). Spatial autocorrelation analyses test the hypothesis of spatial independence in the distribution of numbers of seeds at each sample location by calculating levels of autocorrelation with increasing distance apart of the samples. Aggregated distributions may result in significant autocorrelation at one or more distances, providing a measure of mean clump size (Dale et al. 2002). All spatial pattern analyses were conducted using SpPack (Perry 2004).

\section{RESULTS}

\section{Extant vegetation and soil nutrients}

Extant vegetation richness ranged from 74 species at Limestone to 114 species at Crest (Table 1). The number of canopy seed storage (serotinous) species was lowest at Limestone (12 species; 13\% of total extant species richness) and highest at Crest (28 species; 24\%) and Swale (29 species; $28 \%$ ). Most other extant species were characterized by soil seed storage. Species richness of non-sprouters was highest for the two tall shrubland sites (39 species at Crest and 33 species at Limestone), with tall shrubs contributing to this number at both sites and annuals (including exotics) in particular at Limestone (Table 1). Resprouter species richness ranged from $41(55 \%)$ at Limestone to $79(74 \%)$ at Swale, although the highest percentage of resprouters was at Laterite (78\%). The distribution of extant species richness among soil vs. canopy seed storage modes by sites was significantly different $\left(\chi^{2}\right.$ test; $\left.P<0.01\right)$, reflecting higher-than-expected occurrence of canopy storage plant species and lower-than-expected occurrence of soil storage species at Crest, Swale, and Laterite and the opposite at Limestone.

Soil nutrient levels were generally low, but were significantly higher at Limestone than at Crest and Swale for total $\mathrm{N}$ and $\mathrm{S}$, exchangeable $\mathrm{Ca}$, and Colwell's $\mathrm{K}$ (Table 2). Laterite showed levels intermediate between Limestone and the other sites for most nutrients, while Crest showed the lowest nutrient levels, with total $\mathrm{P}$ significantly lower than at any of the other sites. Overall, Limestone was characterized by lower species richness, lower fraction of resprouter and canopy seed storage 
TABLE 2. Soil pH and concentrations of major soil nutrients at four shrubland sites near Eneabba, southwestern Australia.

\begin{tabular}{lcccccc}
\hline \hline \multicolumn{1}{c}{ Site } & Soil pH & $\begin{array}{c}\text { Exchangeable Ca } \\
(\mathrm{mg} / \mathrm{kg})\end{array}$ & Total N $(\mathrm{mg} / \mathrm{kg})$ & Total S $(\mathrm{mg} / \mathrm{kg})$ & Colwell P $(\mathrm{mg} / \mathrm{kg})$ & Colwell K $(\mathrm{mg} / \mathrm{kg})$ \\
\hline Crest & $6.2^{\mathrm{c}} \pm 0.0$ & $8.9^{\mathrm{c}} \pm 0.3$ & $3.5^{\mathrm{c}} \pm 0.1$ & $4.0^{\mathrm{b}} \pm 0.2$ & $2.9^{\mathrm{b}} \pm 0.1$ & $31.3^{\mathrm{c}} \pm 1.0^{\mathrm{a}}$ \\
Swale & $6.1^{\mathrm{b}, \mathrm{c}} \pm 0.0$ & $8.1^{\mathrm{c}} \pm 0.3$ & $4.5^{\mathrm{b}} \pm 0.2$ & $4.4^{\mathrm{b}} \pm 0.2$ & $3.7^{\mathrm{a}} \pm 0.2$ & $36.9^{\mathrm{b}} \pm 0.9$ \\
Laterite & $6.1^{\mathrm{b}} \pm 0.0$ & $19.6^{\mathrm{b}} \pm 0.8$ & $4.8^{\mathrm{b}} \pm 0.2$ & $4.7^{\mathrm{b}} \pm 0.2$ & $4.0^{\mathrm{a}} \pm 0.2$ & $50.8^{\mathrm{a}} \pm 1.8^{\mathrm{a}}$ \\
Limestone & $6.7^{\mathrm{a}} \pm 0.0$ & $34.1^{\mathrm{a}} \pm 1.9$ & $7.4^{\mathrm{a}} \pm 0.3$ & $6.5^{\mathrm{a}} \pm 0.9$ & $4.0^{\mathrm{a} \pm 0.1}$ & $55.6^{\mathrm{a}} \pm 1.7$ \\
\hline
\end{tabular}

Notes: Data are means \pm SE. Values within columns followed by the same letter are not significantly different (ANOVA and Tukey comparison of means, $P<0.05$ ). Sample size is $n=90$ for each site. Soil samples were subsampled from the samples collected for bulk germination of soil-stored seeds.

species, more annuals and exotics, and higher soil $\mathrm{pH}$ and nutrient availability. Laterite and Swale were characterized by lower vegetation (dominated by subshrubs $<1 \mathrm{~m}$ height), higher plant density, and greater richness and abundance of the grass/sedge/rush life form, while Crest included tall shrub (1-2.5 m tall) and a few small tree (3-5 m tall) species.

\section{Seed banks}

The number of SSB species recorded as germinants ranged from 38 at Crest to 56 at Laterite (Table 3). Numbers of both exotic and annual species were much higher than found in the extant vegetation, with richness of annuals at Limestone (20 species) nearly twice that at any other site. Only 13-21 SSB species per site (34-40\%) were also present in the extant vegetation at that site, while many more potential soil storage species (44-69 species per site) present in the extant vegetation were absent from the SSB. Non-sprouter species richness was higher than resprouter species richness at Limestone, Crest, and Swale and about equal at Laterite, representing a shift towards non-sprouters in species composition of the SSB relative to the extant vegetation (Tables 1 and 3). Jackknife 1 and 2 estimates of SSB richness were 9 (jackknife 1; Limestone) to 37 (jackknife 2; Laterite) species higher than the sample estimates, implying that a greater sampling intensity may have found more species. However, these numbers are still much lower than the actual numbers for "missing" extant species at each site (Table 3). All of the perennial species recorded in the SSB were also present in the extant vegetation.

The number of CSB species per site ranged from 12 (Limestone) to 26 (Crest and Swale). While all extant CSB species at Limestone stored seeds, two to three species at each of the other sites showed no evidence of seed production or storage (Table 3 ). Nevertheless, the percentage of extant CSB species with recorded seed storage was high $(90-100 \%)$ compared with that for SSB species (34-40\%). The four CSB species that failed to store seeds were all resprouters. In contrast to dominance of the SSB by non-sprouters, resprouters strongly dominated the CSB, comprising from $58 \%$ to $85 \%$ of CSB species (Table 3).

The frequency of occurrence of species by seed dispersal modes did not differ between sites for extant vegetation or seed bank types ( $\chi^{2}$ test, $P>0.05$ in all cases), but did differ between SSB and CSB (Table 4). Barochores dominated the SSB, with ants (mymechocory) and wind also important and a few species dispersed by birds (internal). The CSB species were all either anemochores or barochores, with wind the dominant dispersal agent. Overall, SSB species composition reflected the distribution of dispersal mechanisms represented in the extant vegetation, albeit with wind dispersal underrepresented. The distribution of species among seed size categories was consistent among sites for extant vegetation and seed bank types ( $\chi^{2}$ test, $P>$ 0.05 in all cases), but again differed markedly between SSB and CSB: the former had more small-seeded and fewer large-seeded species than expected, while seed size

TABLE 3. Floristic richness (number of species) of the soil seed bank (per 90 soil samples of $14 \times 14 \times 5 \mathrm{~cm}$ ) and canopy seed bank for four shrubland sites near Eneabba, southwestern Australia.

\begin{tabular}{|c|c|c|c|c|c|c|c|c|c|c|c|c|}
\hline \multirow[b]{2}{*}{ Site } & \multicolumn{7}{|c|}{ SSB } & \multicolumn{5}{|c|}{ CSB } \\
\hline & $\begin{array}{c}\text { Total } \\
\text { species }\end{array}$ & $\begin{array}{c}\text { Non- } \\
\text { sprouters }\end{array}$ & $\begin{array}{c}\mathrm{Re}- \\
\text { sprouters }\end{array}$ & Annuals & $\begin{array}{c}\text { In } \\
\text { common }\end{array}$ & Missing & $\begin{array}{l}\text { Jack- } \\
\text { knife }\end{array}$ & $\begin{array}{c}\text { Total } \\
\text { species }\end{array}$ & $\begin{array}{c}\text { Non- } \\
\text { sprouters }\end{array}$ & $\begin{array}{c}\mathrm{Re}- \\
\text { sprouters }\end{array}$ & $\begin{array}{c}\text { In } \\
\text { common }\end{array}$ & Missing \\
\hline Crest & 38 & 22 & 16 & $10(3)$ & 13 & 69 & $50-52$ & 26 & 8 & 18 & 26 & 2 \\
\hline Swale & 40 & 23 & 17 & $12(4)$ & 16 & 59 & $59-72$ & 26 & 6 & 20 & 26 & 3 \\
\hline Laterite & 56 & 27 & 29 & 11 (3) & 21 & 52 & 79-93 & 20 & 3 & 17 & 20 & 2 \\
\hline Limestone & 50 & 35 & 15 & $20(5)$ & 18 & 44 & $59-66$ & 12 & 5 & 7 & 12 & 0 \\
\hline All & 117 & 65 & 44 & $31(9)$ & 3 & 144 & & 49 & 13 & 36 & 49 & 4 \\
\hline
\end{tabular}

Notes: "Non-sprouters" columns report non-sprouter species richness (including annuals), and "Resprouters" columns report resprouter species richness. In the "Annuals" column, values in parentheses are numbers of exotic annuals. "In common" is the number of species shared between the seed banks and extant vegetation. "Missing" is the number of species present in the extant vegetation but not recorded in the soil seed bank or canopy seed bank. "Jackknife" shows jackknife 1 - jackknife 2 estimates of soil seed bank species richness. 
TABLE 4. Species richness (number of species) of extant vegetation, the canopy seed bank (CSB), and the soil seed bank (SSB) in relation to mode of seed dispersal and seed size for four shrubland sites (Crest, Swale, Laterite, Limestone) near Eneabba, southwestern Australia.

\begin{tabular}{|c|c|c|c|c|c|c|c|c|c|}
\hline \multirow{2}{*}{$\begin{array}{c}\text { Source } \\
\text { and site }\end{array}$} & \multirow{2}{*}{$\begin{array}{l}\text { Total no. } \\
\text { species }\end{array}$} & \multicolumn{5}{|c|}{ No. species, by dispersal mode } & \multicolumn{3}{|c|}{ No. species, by seed size } \\
\hline & & Ant & Bird & None & Wind & Other & Large & Moderate & Small \\
\hline \multicolumn{10}{|l|}{ Extant } \\
\hline Crest & 114 & 33 & 7 & 32 & 41 & 1 & 15 & 58 & 41 \\
\hline Swale & 104 & 26 & 8 & 38 & 30 & 2 & 13 & 49 & 42 \\
\hline Laterite & 95 & 26 & 4 & 38 & 24 & 3 & 9 & 38 & 48 \\
\hline Limestone & 74 & 30 & 8 & 17 & 16 & 5 & 11 & 29 & 34 \\
\hline \multicolumn{10}{|l|}{ CSB } \\
\hline Crest & 28 & 0 & 0 & 7 & 21 & 0 & 11 & 9 & 8 \\
\hline Swale & 29 & 0 & 0 & 9 & 20 & 0 & 7 & 13 & 9 \\
\hline Laterite & 22 & 0 & 0 & 7 & 15 & 0 & 4 & 11 & 7 \\
\hline Limestone & 12 & 0 & 0 & 2 & 10 & 0 & 4 & 6 & 2 \\
\hline \multicolumn{10}{|l|}{ SSB } \\
\hline Crest & 38 & 6 & 3 & 19 & 9 & 2 & 1 & 11 & 24 \\
\hline Swale & 40 & 10 & 4 & 17 & 8 & 1 & 2 & 14 & 23 \\
\hline Laterite & 56 & 13 & 3 & 28 & 9 & 3 & 0 & 15 & 41 \\
\hline Limestone & 50 & 11 & 2 & 22 & 11 & 3 & 2 & 14 & 34 \\
\hline
\end{tabular}

Notes: See Methods for details of dispersal and seed size categories. "Other" includes seeds with attachments for external dispersal by animals and seeds with no dormancy.

categories were more evenly represented among CSB species (Table 4).

The density of germinants from SSB samples ranged from 233 to 1435 seedlings $/ \mathrm{m}^{2}$ (Table 5). Densities were highest at Limestone, intermediate at Laterite, and lowest at Crest and Swale, and differences among sites were significant. The much higher seedling densities at Limestone and Laterite were largely contributed by the abundance of native winter annuals, which were also characterized by small seed size. Perennial species were generally infrequent. Seedling density for perennial resprouters was consistently low at all four sites, while that for non-sprouters was low at Crest, Swale, and Laterite, but much higher at Limestone (Table 4). There was no evidence for higher seed (production and) storage in non-sprouters than resprouters.

The estimated number of germinable seeds per square meter in the CSB was higher and more uniform among sites than that for the SSB, with seed stores ranging from 625 seeds $/ \mathrm{m}^{2}$ at Laterite to 1558 seeds $/ \mathrm{m}^{2}$ at Limestone (Table 6). Seed store was generally $>30$ seeds/plant (and often $>100$ ) for non-sprouters, although several species showed lower seed store at Swale than at other sites. The estimated number of firm seeds per plant ranged from zero for several large-seeded resprouting shrubs to $>1000$ in three small-seeded resprouting shrubs (Appendix A). Since both plant density and seed store per plant ranged over several orders of magnitude, the estimated number of firm seeds per square meter was also highly variable, ranging from zero (or near zero) for infrequent, low-seed-producing species, to $>100$ seeds $/ \mathrm{m}^{2}$ for several small-seeded (all Myrtaceae) species. Two resprouter (both Proteaceae) species had estimated firm-seed stores of $>500 /$ plant, but low seed viability reduced estimated viable seeds per square meter to near zero. There was no correlation between mean germinable seed store per plant and germination rate $(r$ $=0.17, \mathrm{df}=58, P>0.05)$ and no difference in germinable seed store per plant for resprouter vs. nonsprouter species overall $(t=-1.87, \mathrm{df}=71, P>0.05)$ or in germination rate, which was almost identical for the two groups (non-sprouters, $68 \% \pm 8 \%$; resprouters, $67 \%$ $\pm 4 \%$; mean $\pm \mathrm{SE}$ ).

Level of serotiny varied markedly between CSB species. A few retained seeds in closed fruits for only 1-2 years, while others retained seeds for $>10$ years.

TABLE 5. Density of soil seed bank (SSB) germinants for four sites in shrublands near Eneabba, southwestern Australia.

\begin{tabular}{|c|c|c|c|c|c|c|}
\hline \multirow[b]{2}{*}{ Site } & \multicolumn{4}{|c|}{ Total } & \multicolumn{2}{|c|}{ Perennial } \\
\hline & All (no. $\left./ \mathrm{m}^{2}\right)$ & Exotic (no. $/ \mathrm{m}^{2}$ ) & Annual (no. $\left./ \mathrm{m}^{2}\right)$ & Perennial (no. $/ \mathrm{m}^{2}$ ) & $\begin{array}{l}\text { Non-sprouter } \\
\left(\text { no. } / \mathrm{m}^{2}\right)\end{array}$ & $\begin{array}{c}\text { Resprouter } \\
\left(\text { no. } / \mathrm{m}^{2}\right)\end{array}$ \\
\hline Crest & $233^{\mathrm{a}} \pm 17$ & $44^{\mathrm{a}} \pm 10$ & $54^{\mathrm{a}} \pm 10$ & $178^{\mathrm{a}, \mathrm{b}} \pm 11$ & $40^{\mathrm{a}} \pm 8$ & $138^{\mathrm{a}} \pm 11$ \\
\hline Swale & $264^{\mathrm{a}} \pm 20$ & $39^{\mathrm{a}} \pm 10$ & $67^{\mathrm{a}} \pm 11$ & $197^{\mathrm{a}} \pm 11$ & $61^{a} \pm 13$ & $136^{\mathrm{a}} \pm 9$ \\
\hline Laterite $\dagger$ & $965^{\mathrm{b}} \pm 116$ & $3^{b} \pm 8$ & $615^{\mathrm{b}} \pm 37$ & $149^{\mathrm{b}} \pm 14$ & $55^{\mathrm{a}} \pm 15$ & $94^{\mathrm{b}} \pm 13$ \\
\hline Limestone & $1435^{\mathrm{b}} \pm 129$ & $71^{\mathrm{c}} \pm 11$ & $1122^{\mathrm{c}} \pm 36$ & $310^{c} \pm 15$ & $262^{c} \pm 15$ & $48^{\mathrm{c}} \pm 12$ \\
\hline
\end{tabular}

Notes: Data are means \pm SE. Values within columns followed by the same letter are not significantly different (Tukey comparison of means, $P<0.05$ ). Sample size is $n=90$ for each site.

$\dagger$ Due to the large number of dead unknowns, totals do not always sum to overall density of germinants $/ \mathrm{m}^{2}$ for the Laterite site. 
TABLE 6. Estimated seed bank size (no. germinants $/ \mathrm{m}^{2}$ ) for four shrubland sites near Eneabba, southwestern Australia.

\begin{tabular}{lccc}
\hline \hline \multicolumn{1}{c}{ Site } & $\begin{array}{c}\text { SSB } \\
\left(\text { no. } / \mathrm{m}^{2}\right)\end{array}$ & $\begin{array}{c}\text { CSB } \\
\left(\text { no. } / \mathrm{m}^{2}\right)\end{array}$ & $\begin{array}{r}\text { Total } \\
\left(\text { no. } / \mathrm{m}^{2}\right)\end{array}$ \\
\hline Crest & $233 \pm 17$ & 1132 & 1365 \\
Swale & $264 \pm 20$ & 836 & 1100 \\
Laterite & $965 \pm 116$ & 625 & 1590 \\
Limestone & $1435 \pm 129$ & 1558 & 2993 \\
\hline
\end{tabular}

Note: Data are means \pm SE for: CSB, canopy seed bank; SSB, soil seed bank; and total, the sum of CSB and SSB.

Most serotinous species retained seeds for three to seven years. There was a significant correlation between level of serotiny and seed mass $(r=0.34, \mathrm{df}=53, P=0.01)$ with a tendency for large-seeded species to hold seeds in the crown longer than small-seeded species. However, there was no relationship between level of serotiny (seed longevity) and size of canopy seed store (viable seeds per plant).

The estimated percentage of projected foliage cover and mean dry mass of litter were high for vegetated patches and low for bare patches, but there was no significant difference in either SSB density or species richness per sample for bare vs. vegetated locations at any site (Table 7). Nor was there any difference in germinant densities between bare and vegetated patches for annuals and perennials, resprouters and nonsprouters, or in relation to dispersal mode and seed size. In most cases, sample sizes were too small to allow individual species comparisons, and among those comparisons possible, there were no significant differences.

Spatial autocorrelation analyses (Moran's $I$ and Geary's $C$ ) showed significant spatial structure for some SSB species, with evidence of clumping at a range of scales up to $10 \mathrm{~m}$, (Appendix B). Geary's $C$ provided stronger evidence of aggregation than did Moran's $I$, with twice as many comparisons (19 of 41 species) revealing significant autocorrelation at scales $<2 \mathrm{~m}$. Nearly all woody non-sprouter species ( 8 of 11 species comparisons) showed significant aggregation at these scales, while half or fewer did so for annuals and herbaceous resprouters. No woody resprouter species had sufficient sample size for analysis, and there was little consistency in results for other life history attribute groupings.

\section{Relationship between extant vegetation and seed banks}

Sorensen's index of similarity (IS) for extant vegetation ranged from $16 \%$ for Crest vs. Limestone to 53\% for Crest vs. Swale (Table 8a). Similarity in SSB species composition ranged from $17 \%$ for Crest/Laterite to $50 \%$ for Crest/Swale. Crest and Swale both showed low extant similarity to Limestone (16\% and $20 \%$ ), but much higher SSB similarity (46\% and $45 \%$ ). The CSB showed the greatest range in IS between sites, from $14 \%$ for Crest/Limestone to $59 \%$ for Crest/Swale.

Similarity in composition between SSB and extant vegetation within each site ranged from 26\% (Crest and Swale) to $43 \%$ (Limestone), while that between extant vegetation and CSB ranged from $27 \%$ to $42 \%$ and showed the opposite pattern, with lowest similarity at Limestone and highest at Crest and Swale (Table 8b). The level of similarity increased to $54-57 \%$ when overall seed bank species composition (canopy plus soil) was compared to that of the extant vegetation. Although 40$60 \%$ of SSB species were also present in the extant vegetation (with greatest similarity at Limestone), the majority of extant species at each site (58-98 species) were absent from the SSB and most of these were woody perennials. After taking CSB species into account, there were still from 44 to 69 species present in the extant vegetation that were not recorded in the seed banks.

TABLE 7. Comparison of percentage (mean $\pm \mathrm{SE}$ ) of projective foliage cover, dry mass of litter, plant species richness, and germinant density per sample for vegetated vs. bare soil seed bank sample locations in four shrubland sites near Eneabba, southwestern Australia.

\begin{tabular}{lcrccc}
\hline \hline $\begin{array}{l}\text { Site and } \\
\text { position }\end{array}$ & $N$ & Cover $(\%)$ & $\begin{array}{c}\text { Litter dry mass } \\
\left(\mathrm{g} / \mathrm{m}^{2}\right)\end{array}$ & $\begin{array}{c}\text { Species richness } \\
\left(\text { no. } / \mathrm{m}^{2}\right)\end{array}$ & $\begin{array}{c}\text { Density of germinants } \\
\left(\text { no. } / \mathrm{m}^{2}\right)\end{array}$ \\
\hline Crest & & & & & \\
$\quad$ Vegetated & 80 & $21.0^{\mathrm{b}} \pm 2.2$ & $11.7^{\mathrm{b}} \pm 0.9$ & $2.9^{\mathrm{a}} \pm 0.2$ & $4.7^{\mathrm{a}} \pm 0.3$ \\
$\quad$ Bare & 10 & $1.4^{\mathrm{a}} \pm 0.6$ & $3.6^{\mathrm{a}} \pm 0.7$ & $2.5^{\mathrm{a}} \pm 0.7$ & $4.0^{\mathrm{a}} \pm 1.0$ \\
Swale & & & & & \\
$\quad \begin{array}{l}\text { Vegetated } \\
\text { Bare }\end{array}$ & 72 & $11.1^{\mathrm{b}} \pm 1.3$ & $7.3^{\mathrm{b}} \pm 0.7$ & $3.4^{\mathrm{a}} \pm 0.2$ & $5.5^{\mathrm{a}} \pm 0.5$ \\
$\quad 18$ & $1.2^{\mathrm{a}} \pm 0.3$ & $5.0^{\mathrm{a}} \pm 1.0$ & $2.8^{\mathrm{a}} \pm 0.4$ & $4.5^{\mathrm{a}} \pm 0.8$ \\
Laterite & & & & & \\
$\quad$ Vegetated & 70 & $41.4^{\mathrm{b}} \pm 2.9$ & $34.0^{\mathrm{b}} \pm 2.6$ & $5.3^{\mathrm{a}} \pm 0.3$ & $19.5^{\mathrm{a}} \pm 2.8$ \\
$\quad$ Bare & 20 & $8.9^{\mathrm{a}} \pm 2.1$ & $16.8^{\mathrm{a}} \pm 4.3$ & $6.2^{\mathrm{a}} \pm 0.5$ & $19.7^{\mathrm{a}} \pm 3.1$ \\
Limestone & & & & & \\
$\quad$ Vegetated & 70 & $23.0^{\mathrm{b}} \pm 2.6$ & $13.9^{\mathrm{b}} \pm 1.2$ & $7.6^{\mathrm{a}} \pm 0.4$ & $27.0^{\mathrm{a}} \pm 3.1$ \\
$\quad$ Bare & 20 & $0.8^{\mathrm{a}} \pm 0.4$ & $6.4^{\mathrm{a}} \pm 1.1$ & $8.1^{\mathrm{a}} \pm 0.5$ & $32.3^{\mathrm{a}} \pm 3.9$ \\
\hline
\end{tabular}

Notes: Data are means \pm SE. Within columns and sites, values with the same superscript letter for vegetated and bare areas indicates no significant difference $(t$ test, $P<0.05)$. $N$ is the number of sample locations. 
TABle 8. Similarity (Sorensen's index) in plant species composition (a) between sites, for extant vegetation, the soil seed bank (SSB), and the canopy seed bank (CSB), and (b) within sites, for seed bank composition (SSB, CSB, and combined SSB + CSB) compared with extant vegetation, for four shrubland sites near Eneabba, southwestern Australia.

\begin{tabular}{lcccc}
\hline \hline \multicolumn{1}{c}{ Site } & Extant & SSB & CSB & $\begin{array}{c}\text { SSB } \\
+ \text { CSB }\end{array}$ \\
\hline a) Between sites & & & & \\
$\quad$ Crest-Swale & 0.53 & 0.50 & 0.59 & \\
Crest-Limestone & 0.16 & 0.46 & 0.14 & \\
Crest-Laterite & 0.28 & 0.17 & 0.31 & \\
$\quad$ Swale-Limestone & 0.20 & 0.45 & 0.23 & \\
$\quad$ Swale-Laterite & 0.46 & 0.23 & 0.43 & \\
$\quad$ Limestone-Laterite & 0.25 & 0.31 & 0.33 & \\
b) Within sites & & & & \\
$\quad$ Crest & & 0.26 & 0.40 & 0.54 \\
$\quad$ Swale & & 0.26 & 0.42 & 0.54 \\
$\quad$ Limestone & & 0.43 & 0.27 & 0.57 \\
$\quad$ Laterite & & 0.36 & 0.35 & 0.57 \\
\hline
\end{tabular}

There was a significant correlation between abundance of extant serotinous plant species and estimated viable seeds per plant $(r=0.36, \mathrm{df}=73, P<0.01)$. While this correlation was influenced by a few abundant Myrtaceae species, it remained significant following their removal from the analysis $(r=0.29, \mathrm{df}=70, P<$ 0.05). Extant abundance of serotinous species was related to the estimated size of viable canopy seed store per plant and mode of regeneration (resprouter/nonsprouter) in a regression model:

$$
\begin{aligned}
\text { extant density }= & 306+0.10(\text { viable seeds } / \text { plant }) \\
& -117(\text { regeneration mode })
\end{aligned}
$$

where regeneration mode assumes categorical values of 1 (non-sprouter) or 2 (resprouter) $\left(r^{2}=0.21, \mathrm{df}=2,80, F=\right.$ 10.6, $P<0.001)$. An ANCOVA model further explored this relationship, with both mode of regeneration (nonsprouter/resprouter) and taxonomic family (Proteaceae/Myrtaceae) as factors and estimated canopy seed store per plant as a covariate. The model was highly significant for both factors, the interaction between factors, and the covariate, accounting for $58.7 \%$ of the variance in extant density of plant species (Appendix C).

\section{Discussion}

The SSB densities recorded in our study were low to moderate (233-1435 seeds $/ \mathrm{m}^{2}$ ) compared with those for Mediterranean-type vegetation elsewhere (hypothesis 1): $1050-1800$ seeds $/ \mathrm{m}^{2}$ for shrublands in Spain (Valbuena and Trabaud 2001), $1683-4518 / \mathrm{m}^{2}$ for South African fynbos (Pierce and Cowling 1991a,b), 4575/ $\mathrm{m}^{2}$ for a southeastern Australian sand heath (Wills and Read 2002), up to $12547 \pm 449 / \mathrm{m}^{2}$ (mean $\pm \mathrm{SE}$ ) for a southeastern Australian heathy woodland (Enright and Kintrup 2001), and $8000-25000 / \mathrm{m}^{2}$ in Californian chaparral (Zammit and Zedler 1988). They were similar to those reported for other dry Mediterranean-type vegetation in southwestern Australia: 919-1545/m² (Meney et al. 1994) and $156 / \mathrm{m}^{2}$ (Bellairs and Bell 1993) for shrublands and 377-1579/ $\mathrm{m}^{2}$ (Vlahos and Bell 1986) for dry sclerophyll forest.

Canopy seed bank size ranged from 625 to 1558 seeds $/ \mathrm{m}^{2}$ and was high relative to results reported by the few other studies of canopy seed storage: Bellairs and Bell (1990) estimated seed bank sizes of 104-287 seeds $/ \mathrm{m}^{2}$ for four plant communities in Western Australia. Bond (1985) conducted a general survey of serotiny in the Southern Cape for 12 species in the genera Protea and Leucadendron (Proteaceae), a region considered second only to southwestern Australia in richness of serotinous species (Lamont et al. 1991). Community level estimates of CSB size were not attempted by Bond, but are estimated by us to be $<100$ seeds $/ \mathrm{m}^{2}$. When considered in combination (SSB + CSB), the CSB increased total seed bank size by one to four times to $1100-2993$ seeds $/ \mathrm{m}^{2}$ for the four sites examined here.

According to Bell (2001), the fraction of resprouting species is extremely high in southwestern Australian shrublands (60-80\% of species) and thus may contribute to the explanation of small SSB size since resprouters generally produce fewer seeds than non-sprouters (Lamont and Wiens 2003). However, Vesk and Westoby (2004) and Pausas et al. (2004) report similar (high) levels of resprouting in relation to disturbance for a range of other ecosystems, including fire-prone shrublands and forests, so that resprouting alone is unlikely to account for the low seed bank size. Nevertheless, seed production was low in many of the serotinous resprouter species assessed here, and there was a marked shift from dominance of the extant vegetation by resprouters to dominance of the SSB by non-sprouters, indicating reduced relative representation of resprouters in the SSB. More importantly, the CSB increased overall seed bank size markedly from sometimes very low levels. Since serotiny is infrequent or absent in most other Mediterranean systems, we conclude that the CSB makes a major contribution to total seed stores in southwestern Australian shrublands and at least partly explains small SSB size in some sites.

Generally low soil nutrient supply in southwestern Australian shrubland ecosystems (Cowling et al. 1996) relative to other Mediterranean regions may constrain the competitiveness of small-seeded, fast-growing herbaceous species compared with larger-seeded, slowgrowing woody species (Bond 1989), resulting in small SSB size (hypothesis 2). Sites with the smallest SSB here (Crest, Swale) had a low density and species richness of annuals and had low soil nutrient levels. Sites with greater SSB size (Limestone, Laterite) were more nutrient-rich and had higher densities of annuals, with species richness of annuals also high at the site with highest soil nutrient levels (Limestone). High density of annuals in the SSB is reported for other Mediterraneantype regions by Holmes and Cowling (1997) and 
Valbuena and Trabaud (2001), while Cowling et al. (1996) report that annuals comprise $15 \%$ or more of the local floras in most Mediterranean climate regions, but are infrequent in Australia. The combination of a depauperate annual flora and low soil nutrient supply may contribute to low SSB size in the present study, with low nutrient supply limiting seed production of annuals at some sites. However, there was no difference in the distribution of seed sizes among SSB species between sites and so no evidence for a seed size-seed number trade-off in relation to soil nutrient level.

Resprouter species outnumbered non-sprouters in the extant vegetation at all sites, and the majority of extant CSB species were also resprouters. Contrary to the findings of many previous studies (e.g., Groom and Lamont 1996, Lamont and Weins 2003), CSB resprouter species showed higher (rather than lower) levels of seed storage per plant than did non-sprouter species. This result was driven by a seed size-seed production tradeoff across many plant species and several families, with large seed stores of very small seeds in some common resprouter shrubs and much lower seed stores among both resprouter and non-sprouter species with larger seed size. However, among species with moderate and large seeds, seed stores were significantly greater for non-sprouter species. Low, or no, seed store for CSB species was restricted to a few resprouters, so that while resprouters still dominated the $\mathrm{CSB}$, there was a relative increase in non-sprouter species richness. This trend was much stronger for the SSB, with non-sprouters comprising $50 \%$ or more of species in all sites due to increased occurrence of annuals and low representation of resprouters compared with perennial non-sprouters from the extant vegetation. Overall, there was only weak support for the hypothesis of low seed bank storage among resprouter species due to low seed production (hypothesis 3). However, high seed storage among small-seeded resprouter shrub species does not necessarily imply high rates of recruitment from the seed bank after fire in these shrublands. For species with seeds of similar size, survivorship of non-sprouters is greater than that of resprouters (Enright and Lamont 1989, Lamont et al. 1993, Pausas et al. 2004), and for seeds of different size and similar leaf morphology, seedling establishment and survival is positively correlated with seed size (Lamont et al. 1999).

Similarity in species composition between the SSB and extant vegetation was low at all sites (26-43\%), with levels similar to those reported for shrublands elsewhere: e.g., 23\% in Spain (Valbuena and Trabaud 2001), 25$32 \%$ in South Africa (Holmes and Cowling 1997), and "low" for Chilean matorral (Figueroa et al. 2004). Low similarity is generally reported to be a consequence of dominance of extant vegetation by perennial species but seed banks by annuals and ephemerals (Thompson 1978, 2000), and this is at least partly true for the SSB sites examined here, with annuals better represented in the SSB than in the extant vegetation. Total $(\mathrm{SSB}+\mathrm{CSB})$ seed bank similarity here was higher $(54-57 \%)$ than reported elsewhere for shrublands (hypothesis 4) and most other ecosystem types apart from grasslands rich in annual species (Peco et al. 1998). High similarity between SSB and extant vegetation is generally associated with frequent disturbance, which limits the opportunities for long-lived species to establish. However, the disturbance-prone shrublands of southwestern Australia are strongly dominated by perennial species, and high similarity between SSB and vegetation in these shrublands occurs despite a low richness of annual species. The combination of a high percentage of resprouters in mature shrubland vegetation and high overall similarity of seed bank species composition to extant species composition facilitated by the CSB may help to buffer these shrublands against rapid change in species composition and dominance after fire. If time since last fire was either shorter or longer than the 12-20 years for the present sites, then variation among species in age to reproductive maturity, time to senescence, seed survival, and recruitment in the absence of fire would alter the absolute contributions of species to seed banks, but the relative contributions would remain similar. However, either extremely short $(<7$ years, many species failing to accumulate sufficient seeds for post-fire recruitment) or long ( $>40$ years, many species senesced and seed banks lost) intervals between successive fires would lead to marked changes in seed density and species composition of seed banks and in post-fire community composition (Groeneveld et al. 2002).

Figueroa et al. (2004) noted significantly higher species richness and seed bank density, particularly for grass species, in open microsites in Chilean matorral. They argued that small, short-lived species may establish and reproduce preferentially in open microsites, reinforcing seed bank differences between open and vegetated patches due to relatively short dispersal distances. Guo et al. (1998) reported a significant difference in soil seed bank abundance levels between vegetated and bare areas for desert vegetation in North America, but in the opposite direction: seed bank size decreased with distance from shrubs for most species apart from a few small-seeded grasses and was interpreted to be a consequence of short-distance dispersal. In our southwestern Australian shrubland sites there was no difference in seed species richness or density between open and vegetated microsites, either overall or for species with different regeneration mode, dispersal mode, or life form, so that the SSB was not spatially structured on the basis of these microsite types (hypothesis 5). This suggests that dispersal at the local scale is not a limiting factor for the mostly small-seeded species of the SSB.

There was also little supporting evidence for spatial structure in the distribution of individual SSB species. Spatial autocorrelation at short distances was evident for many non-sprouter shrub species, but not for annuals or herbaceous resprouter species characterized 
by small seeds, possibly reflecting more limited seed dispersal in shrub species (Guo et al. 1998). Most shrub species had moderate or large seeds and were dispersed by ants, birds, or wind, with seeds likely to be incorporated into the SSB close to parent plants unless removed by birds. Low seed store size in woody perennials relative to annuals means that any gradient of decreasing SSB density away from parent plants will rapidly lead to abundance levels at or below the lower limits of detection based on soil sampling.

While the current results provide only weak support for the notion that spatial structuring of these two seed bank types might provide mechanisms facilitating species coexistence, it is possible that such spatial structuring is important when viewed in terms of both space and time. The CSB and SSB are mutually exclusive in species composition and also differ in the timing of seed dispersal in relation to recruitment. The SSB accumulates from annual seed inputs, with seeds of different species dispersed by ants, birds, or wind, and patterns of horizontal and vertical distribution of seeds in the soil are likely to be a function of dispersal vector behavior and time, as shown here and elsewhere. Recruitment after fire depends on the exposure of seeds to heat and smoke, with seeds too close to the soil surface at risk of incineration and those buried too deep at risk of missing the germination cue (Brown et al. 2003). The CSB species are almost solely wind-dispersed (Bond 1985, Lamont et al. 1991), with the seed bank released and dispersed en masse immediately after fire. Enright and Lamont (1989) and Lamont et al. (1993) showed that seeds of large-seeded CSB species accumulated (along with other charred plant debris) in surface micro-depressions through wind dispersal across the bared soil surface after fire, so that seed densities were high in some locations and low in others. Largeseededness conferred a competitive advantage in what became seedling recruitment micro-thickets, self- and alien thinning resulting in only a few surviving largeseeded plants (Lamont et al. 1993, Richards and Lamont 1996). In contrast, intervening bare sandy areas supported few seedlings of large-seeded CSB species so that the opportunities for recruitment and survival of SSB species (which are not likely to be redistributed across the soil surface by wind after primary dispersal) may be increased. The outcome of the different dispersal and recruitment patterns between SSB and CSB species, and in relation to seed size, could help to structure the spatial patterning of species in the community such that coexistence among many species is facilitated.

Species from the two seed bank types may partition space in terms of differential establishment in a way analogous to the fire-induced transient niche hypothesis of Cowling (1987) that he saw as working temporally in relation to variations in fire interval and season from one fire to the next. Spatial analysis of post-fire recruitment patterns among species may reveal the extent to which these spatially differentiated processes associated with seed dispersal and recruitment contribute to coexistence. Such spatial variation might supplement the effects of temporal variation in the probability of germination from the seed bank as a result of speciesspecific responses to fluctuations in recruitment (from fire to fire at the same location) in response to fluctuating weather (Rees 1997).

Trade-offs between seed size, production, and longevity are apparent in the CSB, with level of serotiny (duration of canopy seed storage) positively correlated with seed mass and seed production higher in a number of small-seeded species that numerically dominate the canopy seed store. Similar trade-offs have been described by Leishman and Westoby (1998) and Moles et al. (2003) for soil-stored seeds of species from a range of Australian habitat types, contrary to studies elsewhere that generally show greater persistence in the soil for small seeds (Thompson et al. 1998).

Among CSB species, our study revealed a significant relationship between biological attributes associated with likely success in recruiting individuals into the next generation (seed production and seed viability) and the abundance of individuals of those species in the current vegetation. This implies a dominance hierarchy, with past success correlating with likely future success, i.e., abundant plants are abundant because they produce more viable seeds/plant. Such a relationship may contribute to intergenerational stability in community composition at the local scale, so long as recruitment conditions after successive fires at a single site do not always favor the same species (Chesson 2000).

The different methods of assessing seed bank size and composition for the SSB and CSB in this study introduce complications for the interpretation of results that must be recognized. At the scale of the extant vegetation plots, the CSB is fully quantified for species richness, but the mean number of seeds/plant (and so overall seed bank density) is a sample estimate. In the case of the SSB, both species richness and seed densities are sample estimates from soil samples that represent only a small fraction of the total study plot. Despite a sample size greater than that recommended as adequate by Butler and Chazdon (1998), Gross (1990), and others, jackknife estimates of SSB richness suggested that many species likely to have been present in the soil seed bank within the plot were missed or did not receive the appropriate cue for germination. Only by quantifying seedling emergence after fire can these differences be resolved. However, even then, seed bank parameters are likely to be estimated from sample quadrats due to very high seedling density, estimated here to be $>1 \times 10^{6}$ even for the site with the smallest overall seed bank (Swale).

In terms of increasing our understanding of plant species coexistence in high-diversity ecosystems, the present results support the general relevance of the seed mass/seed number trade-off (Leishman 2001) and storage effects (Chesson 2000) provided by seed bank longevities on the one hand and vegetative regrowth on 
the other in damping shifts in species composition (and abundance hierarchies) through time. In addition, the different ways that seeds from the CSB and SSB are dispersed in time (seeds of serotinous species released mostly en masse after fire vs. every year upon seed ripening for soil storage species) and space (anemochorous seeds of serotinous species accumulating in post-fire microsites vs. barochorous and mymechocorous seeds of soil storage species being either generally dispersed or associated with ant nest sites, respectively) are likely to contribute to coexistence by reducing the frequency of interspecific competitive interactions. Analysis of spatial patterns of species establishment and survival in the first few years after fire, together with their functional attributes, will allow further testing of these ideas.

\section{ACKNOWLedgments}

The authors thank the many helpers who assisted with the collection of spatial data on extant species abundances and distributions and Robert Sim for day-to-day care of the soil seed bank germination trial for the Laterite site. This study was funded by Australian Research Council Discovery Project Grant 0353411 to N. J. Enright and B. B. Lamont.

\section{Literature Cited}

Anderson, A. N., and S. C. Morrison. 1998. Myrmecochory in Australia's seasonal tropics: effects of disturbance on distance dispersal. Australian Journal of Ecology 23:483-491.

Bell, D. T. 2001. Ecological response syndromes in the flora of southwestern Australia: fire resprouters versus reseeders. Botanical Review 67:417-440.

Bell, D. T., J. A. Plummer, and S. K. Taylor. 1993. Seed germination ecology in southwestern Western Australia. Botanical Review 59:25-73.

Bellairs, S. M., and D. T. Bell. 1990. Canopy borne seed store in three Western Australian plant communities. Australian Journal of Ecology 15:299-305.

Bellairs, S. M., and D. T. Bell. 1993. Seed-stores for restoration of species-rich shrubland vegetation following mining in Western Australia. Restoration Ecology 1:231-240.

Bond, W. J. 1985. Canopy-stored seed reserves (serotiny) in Cape Proteaceae. South African Journal of Botany 51:181186.

Bond, W. J. 1989. The tortoise and the hare: the ecology of angiosperm dominance and gymnosperm persistence. Biological Journal of the Linnean Society 36:227-249.

Bond, W. J., R. M. Cowling, and M. B. Richards. 1992. Competition and coexistence. Pages 206-225 in R. M. Cowling, editor. The ecology of fynbos. Oxford University Press, Cape Town, South Africa.

Brown, J., N. J. Enright, and B. P. Miller. 2003. Seed production and germination in two rare and three common, co-occurring Acacia species from SE Australia. Austral Ecology 28:271-280.

Butler, B. J., and R. L. Chazdon. 1998. Species richness, spatial variation, and abundance of the soil seed bank of a secondary tropical rain forest. Biotropica 30:214-222.

Chesson, P. 2000. Mechanisms of maintenance of species diversity. Annual Review of Ecology and Systematics 31: 343-366.

Chiarucci, A., N. J. Enright, G. L. W. Perry, B. P. Miller, and B. B. Lamont. 2003. Performance of nonparametric species richness estimators in a high diversity plant community. Diversity and Distributions 9:283-295.

Cowling, R. M. 1987. Fire and its role in coexistence and speciation in Gondwanan shrublands. South African Journal of Science 83:106-112.
Cowling, R. M., and B. B. Lamont. 1985. Seed release in Banksia: the role of wet-dry cycles. Australian Journal of Ecology 10:169-171.

Cowling, R. M., P. W. Rundel, B. B. Lamont, M. Arroyo, and M. Arianoutsou. 1996. Plant diversity in Mediterraneanclimate regions. Trends in Ecology and Evolution 11:362366.

Dale, M. R. T., P. Dixon, M.-J. Fortin, P. Legendre, D. E. Myers, and M. S. Rosenberg. 2002. Conceptual and mathematical relationships among methods for spatial analysis. Ecography 25:558-577.

Enright, N. J., and A. Kintrup. 2001. The effects of smoke, heat and charred wood on the germination of dormant soil-stored seeds from a Eucalyptus baxteri heathy woodland in Victoria, SE Australia. Austral Ecology 26:132-141.

Enright, N. J., and B. B. Lamont. 1989. Seed banks, fire season, safe sites and seedling recruitment in five co-occurring Banksia species. Journal of Ecology 77:1111-1122.

Enright, N. J., and B. B. Lamont. 1992. Survival, growth and water-relations of Banksia seedlings on sand mine tailings and adjacent scrub-heath sites. Journal of Applied Ecology 29:663-671.

Enright, N. J., B. B. Lamont, and R. Marsula. 1996. Canopy seed bank dynamics and optimum fire regime for the highly serotinous shrub, Banksia hookeriana. Journal of Ecology 84: 9-17.

Enright, N. J., B. B. Lamont, and B. P. Miller. 2005. Anomalies in grasstree fire history reconstructions for south-western Australian vegetation. Austral Ecology 30:668-673.

Figueroa, J. A., S. Teillier, and F. M. Jaksic. 2004. Comparison, size and dynamics of the seed bank in a Mediterranean shrubland of Chile. Austral Ecology 29:574-584.

Grant, C. D., and J. M. Koch. 1997. Ecological aspects of soil seed-banks in relation to bauxite mining. 2. Twelve year old rehabilitated mines. Australian Journal of Ecology 22:177184.

Groeneveld, J., N. J. Enright, B. B. Lamont, and C. Wissel. 2002. A spatial model of coexistence among three Banksia species along a habitat gradient in fire-prone shrublands. Journal of Ecology 90:762-774.

Groom, P. K., and B. B. Lamont. 1996. Reproductive ecology of non-sprouting and resprouting species of Hakea (Proteaceae) in southwestern Australia. Pages 239-248 in S. D. Hopper, editor. Gondwanan heritage: past, present and future of the Western Australian flora. Surrey Beatty and Sons, Chipping Norton, UK.

Gross, K. L. 1990. A comparison of methods for estimating seed numbers in the soil. Journal of Ecology 78:1079-1093.

Guo, Q., P. W. Rundel, and D. W. Goodall. 1998. Horizontal and vertical distribution of desert seed banks: patterns, causes, and implications. Journal of Arid Environments 38: $465-478$.

Hnatiuk, R. J., and A. J. M. Hopkins. 1981. An ecological analysis of kwongan vegetation south of Eneabba, Western Australia. Australian Journal of Ecology 6:423-438.

Holmes, E. E., and H. B. Wilson. 1998. Running from trouble: long-distance dispersal and the competitive coexistence of inferior species. American Naturalist 151:578-586.

Holmes, P. M., and R. M. Cowling. 1997. Diversity, composition and guild structure relationships between soilstored seed banks and mature vegetation in alien plant invaded South African fynbos shrublands. Plant Ecology 133:107-122.

Keeley, J. E., and P. H. Zedler. 1998. Evolution of life histories in Pinus. Pages 219-251 in D. M. Richardson, editor. Ecology and biogeography of Pinus. Cambridge University Press, New York, New York, USA.

Lamont, B. B., S. Downes, and J. E. D. Fox. 1977. Importance value curves and diversity indices applied to a species-rich heathland in Western Australia. Nature 265:438-441. 
Lamont, B. B., P. K. Groom, M. B. Richards, and E. T. F. Witkowski. 1999. Recovery of Banksia and Hakea communities after fire - the role of species identity and functional atttributes. Diversity and Distributions 5:15-26.

Lamont, B. B., D. C. Le Maitre, R. M. Cowling, and N. J. Enright. 1991. Canopy seed storage in woody plants. Botanical Review 57:227-317.

Lamont, B. B., and D. Wiens. 2003. Is seed set and speciation always low among species that resprout after fire, and why? Evolutionary Ecology 17:277-292.

Lamont, B. B., E. T. F. Witkowski, and N. J. Enright. 1993. Post-fire litter microsites: safe for seeds, unsafe for seedlings. Ecology 74:501-512.

Legendre, P., and L. Legendre. 1998. Numerical ecology. Second edition. Elsevier, Amsterdam, The Netherlands.

Leishman, M. R. 2001. Does the seed size/number trade-off model determine plant community structure? An assessment of the model mechanisms and their generality. Oikos 93:294302.

Leishman, M. R., and M. Westoby. 1998. Seed size and shape are not related to persistence in soil in Australia in the same way as in Britain. Functional Ecology 12:480-485.

McCune, B., and M. J. Mefford. 1999. PC-ORD 4. Multivariate analysis of ecological data. Version 4.10. MjM Software, Gleneden Beach, Oregon, USA.

Meney, K. A., G. M. Nielssen, and K. W. Dixon. 1994. Seed bank patterns in Restionaceae and Epacridaceae after wildfire in Kwongan in southwestern Australia. Journal of Vegetation Science 5:5-12.

Milberg, P., M. A. Perez-Fernandez, and B. B. Lamont. 1998 Seedling growth response to added nutrients depends on seed size in three woody genera. Journal of Ecology 86:624-632.

Moles, A. T., D. I. Warton, and M. Westoby. 2003. Seed size and survival in the soil in arid Australia. Austral Ecology 28: 575-585.

Nathan, R., U. N. Safriel, and I. Noy-Meir. 2001. Field validation and sensitivity analysis of a mechanistic model for tree seed dispersal by wind. Ecology 81:2156-2169.

Ne'eman, G., S. Goubitz, and R. Nathan. 2004. Reproductive traits of Pinus halapensis in the light of fire - a critical review. Plant Ecology 171:69-79.

Ne'eman, G., and I. Izhaki. 1999. The effect of stand age and microhabitat on SSBs in Mediterranean Aleppo pine forests after fire. Plant Ecology 144:115-125.

Parolin, P. 2000. Seed mass in Amazonian floodplain forests with contrasting nutrient supplies. Journal of Tropical Ecology 16:417-428.

Pausas, J., R. A. Bradstock, D. A. Keith, and J. E. Keeley, and the GCTE Fire Network 2004. Plant functional traits in relation to fire in crown-fire ecosystems. Ecology 85:10851100 .
Peco, B., M. Ortega, and C. Levassor. 1998. Similarity between seed bank and vegetation in Mediterranean grassland: a predictive model. Journal of Vegetation Science 9:815-828.

Perry, G. L. W. 2004. SpPack: spatial point pattern analysis in Excel using Visual Basic for Applications (VBA). Environmental Modelling and Software 19:559-569.

Pierce, S. M., and R. M. Cowling. 1991a. Dynamics of soilstored seed banks of six shrubs in fire-prone dune fynbos. Journal of Ecology 79:731-747.

Pierce, S. M., and R. M. Cowling. 1991b. Disturbance regimes as determinants of seed banks in coastal dune vegetation of the southeastern Cape. Journal of Vegetation Science 2:403412.

Rayment, G. E., and F. R. Higginson. 1992. Australian laboratory handbook of soil and water chemical methods. Inkata Press, Melbourne, Australia.

Rees, M. 1997. Seed dormancy. Pages 214-238 in M. J. Crawley, editor. Plant ecology. Blackwell Science, Oxford, UK.

Richards, M. B., and B. B. Lamont. 1996. Post-fire mortality and water relations of three congeneric shrub species under extreme water stress - A trade-off with fecundity? Oecologia 107:53-60.

Seidler, T. G., and J. B. Plotkin. 2006. Seed dispersal and spatial pattern in tropical trees. PLoS Biology 4:e344 [doi: 10. 1371/journal.pbio.0040344].

Thompson, K. 1978. The occurrence of buried viable seeds in relation to environmental gradients. Journal of Biogeography $5: 425-430$

Thompson, K. 2000. The functional ecology of soil seed banks. Pages 215-236 in M. Fenner, editor. Seeds: the ecology of regeneration in plant communities. CABI Publishing, Oxford, UK.

Thompson, K., J. P. Bakker, R. M. Bekker, and J. G. Hodgson. 1998. Ecological correlates of seed persistence in soil in the north-west European flora. Journal of Ecology 86:163-169.

Valbuena, L., and L. Trabaud. 2001. Contribution of the soil seed bank to post-fire recovery of a heathland. Plant Ecology 152:175-183.

Vesk, P. A., and M. Westoby. 2004. Sprouting ability across diverse disturbances and vegetation types worldwide. Journal of Ecology 92:310-320.

Vlahos, S., and D. T. Bell. 1986. Soil seed-bank components of the northern jarrah forest of Western Australia. Australian Journal of Ecology 11:171-179.

Wills, T. J., and J. Read. 2002. Effects of heat and smoke on germination of soil-stored seed in a south-eastern Australian sand heathland. Australian Journal of Botany 50:197-206.

Zammit, C. A., and P. H. Zedler. 1988. The influence of dominant shrubs, fire and time since fire on soil seed banks in mixed chaparral. Vegetatio 75:175-187.

\section{APPENDIX A}

Size of canopy seed banks for serotinous species at four shrubland sites near Eneabba, southwestern Australia (Ecological Archives E088-138-A1).

\section{APPENDIX B}

Spatial autocorrelation analyses for soil seed bank species at four shrubland sites near Eneabba, southwestern Australia, by site and species attributes for scales 1-10 m (Ecological Archives E088-138-A2).

\section{APPENDIX C}

Analysis of covariance model for the relationship between mode of regeneration, taxonomic family, and extant density of plant species, with estimated canopy seed store size per plant as covariate, for four high-diversity shrubland sites near Eneabba, southwestern Australia (Ecological Archives E088-138-A3). 


\section{ERRATA}

In the June 2007 issue, Ecology 88(6), the Data Paper by Terje Lislevand, Jordi Figuerola, and Tamás Székely ("Avian body sizes in relation to fecundity, mating system, display behavior, and resource sharing"; p. 1605) was published with an error in Terje Lislevand's affiliation. The word "Raleigh" was introduced as a result of an editorial error. The correct affiliation is as follows:

\section{Department of Biology, University of Bergen, Box 7800, N-5020, Bergen, Norway}

We apologize to Dr. Lislevand and to our readers for the mistake in the published version of the paper.

Gregory S. Gilbert, Don R. Reynolds, and Ariadna Bethancourt have discovered errors in their paper ("The patchiness of epifoliar fungi in tropical forests: host range, host abundance, and environment"), which appeared in the March 2007 issue, Ecology 88(3):575-581, as part of the Special Feature on "Ecology of Fungal Symbioses in Tropical Forests." In the second column of Table 1 on p. 577 (reporting the number of sample sites and the percentage with fungi), the data for canopy and understory were interchanged. The numbers in that data column should instead be as follows:

Panama

Canopy $72(16.7 \%)$

Understory $72(43.0 \%)$

Australia

Canopy $120(9.2 \%)$

Understory $120(35.8 \%)$

All the other numbers in the table are correct, and the presentation and discussion in the text are likewise correct.

In the recent paper by N. J. Enright et al. ("Soil vs. canopy seed storage and plant species coexistence in speciesrich Australian shrublands") in the September 2007 issue, Ecology 88(9):2292-2304, the printer introduced a significant error in Table 1 (p. 2296) at a late proof stage. The fourth row of the table should have reported results for "Limestone" sites as shown in the corrected version of the table below:

TABLE 1. Floristic richness (number of species) of extant species for four shrubland sites near Eneabba, southwestern Australia, in relation to mode of regeneration and seed storage.

\begin{tabular}{lcccccc}
\hline \hline \multicolumn{1}{c}{ Site } & Total plant species & Non-sprouters & Resprouters & Annuals & Soil storage & Canopy storage \\
\hline Crest & 114 & 39 & 75 & $3(1)$ & $81(51)$ & 28 \\
Swale & 104 & 26 & 78 & $4(0)$ & $75(35)$ & 29 \\
Laterite & 95 & 21 & 74 & $3(2)$ & $72(34)$ & 22 \\
Limestone & 74 & 33 & 41 & $14(2)$ & $60(32)$ & 12 \\
All & 263 & 75 & 164 & $15(3)$ & $191(101)$ & 53
\end{tabular}

Notes: Numbers in parentheses for annuals are exotic annuals. Numbers in parentheses for soil storage show number of woody species as a subset of all species with soil storage. Non-sprouter numbers also include annuals. Soil storage refers to species whose seeds remain dormant in the soil for $>1$ year following dispersal, requiring a disturbance-related trigger (e.g., heat or smoke from fire) to break dormancy and facilitate germination. Canopy storage refers to species whose seeds are held in a state of enforced dormancy within closed fruits in the plant canopy for $>1$ year so that overlapping annual seed crops accumulate on the plant. Canopy-storage fruits rupture and release their seeds in response to the heat from fires (and sometimes in response to drought, plant death, or fruit aging); the seeds then germinate as soon as appropriate temperature and moisture conditions are encountered.

We apologize to the authors and to our readers for allowing the erroneous version of the table to slip past during proofreading.

Also, the authors have noticed that the units for the last three data columns in the column headings for Table 7 (p. 2299) should all be "per sample" (rather than "per $\mathrm{m}^{2 "}$ "). 